\title{
Effects of the incorporation of residue of masonry on the properties of cementitious mortars
}

Yimmy Fernando Silva (Main and Corresponding Author)

Universidad del Valle, Grupo Materiales Compuestos (GMC)

Calle 13 \# 100-00 edificio 349, Cali (Colombia)

yimmy.silva@correounivalle.edu.co

https://orcid.org/0000-0003-3888-457X

\section{David A. Lange}

University of Illinois at Urbana-Champaign

205 N. Mathews Ave, Illinois (USA)

dlange@illinois.edu

https://orcid.org/0000-0002-6517-711X

\section{Silvio Delvasto}

Universidad del Valle, Grupo Materiales Compuestos (GMC)

Calle 13 \# 100-00 edificio 349, Cali (Colombia)

silvio.delvasto@correounivalle.edu.co

https://orcid.org/0000-0001-9443-8238

Manuscript Code: 14024

Date of Acceptance/Reception: 09.11.2020/08.10.2019

DOI: 10.7764/RDLC.19.3.407

\section{Abstract}

This research presents the results of an experimental study about the potentiality of using residues of masonry (RM), sampled from construction and demolition waste (CDW), as supplementary cementitious material (SCM). The Portland cement was partially replaced by RM up to $50 \%$ in weight ( $0 \%$, $12.5 \%, 25 \%, 37.5 \%$ and $50 \%$ ). Various tests were carried out for: pozzolanic activity (fixed lime and strength activity index), the heat of hydration, setting time, the (autogenous and by drying) shrinkage, and compressive strength. Experimental results shown that the RM has a positive activity because the increase of RM replacement level in the mortars generates a lower heat of hydration and autogenous and drying shrinkage. The fixed lime test at 28 and 180 days, indicated that the RM exhibits pozzolanic activity to some degree, and the Strength Activity Index (SAI) according to ASTM C311, was $77.13 \%$ and $84.36 \%$ at 7 and 28 days, respectively. These results indicate that RM should be considered appropriate for using as supplementary cementitious material.

Keywords: Residue of masonry; supplementary cementitious material; pozzolan; hydration heat; shrinkage.

\section{Introduction}

The construction of civil infrastructure and housing solutions due to Rapid urbanization and larger population is generating a significant impact on the environment because the Portland cement is a fundamental raw material (Dellinghausen, Gastaldini, Vanzin, \& Veiga, 2012; P. Liu et al., 2017; Uysal, Akyuncu, Tanyildizi, Sumer, \& Yildirim, 2019).

Global cement production is the third largest source of anthropogenic carbon dioxide emissions (Rezvani \& Proske, 2017; Andrew, 2018), that reaches approximately to the $7 \%$ of the total global emissions, and between 12 and $15 \%$ of the energy consumed by the industry globally (Gutiérrez, Caballero Eras, Gaviria, Caneghem, \& Vandecasteele, 2017). The production of this binder will reach a top of 4.4 billion tons by 2050, as stated by the World Business Council for Sustainable Development (WBCSD) in 2009 (Maddalena, Roberts, \& Hamilton, 2018). On the other hand, the traditional linear economy model of construction and remodeling of civil works (buildings, houses, roads, etc.) is normal the generation of wastes (Akhtar \& Sarmah, 2018); these leftover materials are the so-called "construction and demolition wastes" (CDW). The CDW represents $25-30 \%$ of all generated wastes in the EU ("Construction and demolition waste Environment - European Commission," 2017). It is estimated that the construction industry will generate $212 \%$ more solid waste by 2050 (de Oliveira Andrade, Possan, Squiavon, \& Ortolan T.L.P., 2018).

The CDW does not have uniform composition, this varies depending on the construction technology, the type of demolition process, kind of civil work, and kind of structure. Generally, CDW includes concrete, mortar, bricks, tiles, ceramics, and in lesser quantities, wood, plastics, glass, plasterboard, and metals (Seco, Omer, Marcelino, Espuelas, \& 
Prieto, 2018). Some researchers have reported that the main constituents of CDW include concrete, mortar, and brick/block (Medina et al., 2015; Zheng et al., 2017). The use of residue of masonry (RM), which is brick of clay with adhered mortar being extracted from CDWs, has a high potential as a partial replacement of cement leading to a lower environmental impact and space savings in landfills since the current management for red brick wastes and other construction leftovers are insufficient to get adequate disposal of them (H. Li, Dong, Jiang, Yang, \& Yang, 2016).

The calcined clays bricks could be used as a pozzolanic material in the production of concrete or mortar (Bediako, 2018; Heikal, Zohdy, \& Abdelkreem, 2013; Kartini, Rohaidah, Zuraini, \& Za, 2012; Naceri \& Hamina, 2009; Silva, Robayo, Mattey, \& Delvasto, 2016). However, the use of brick of clay and mortar waste (Figure 1) as supplementary cementitious material derived from CDW needs further investigation. There are different studies about the pozzolanic properties of brick residues, largely attributed to some of the mineralogical phases presented in the clays used for the preparation of the raw materials for brickmaking. The fired bricks present a certain degree of reactivity due to the loss of crystallinity of some minerals present in the clay when converted into a meta-stable or amorphous phase (Bediako, 2018). One of the minerals used in the elaboration of bricks is the kaolinite, which is abundant in most parts of the world (Harbi, Derabla, \& Nafa, 2017). The clays with the presence of kaolin in their composition when are subjected to a heat treatment between $500{ }^{\circ} \mathrm{C}$ and $900{ }^{\circ} \mathrm{C}$ transform in metakaolin, which is a material with pozzolanic behavior. On the other hand, some artificial pozzolans coming from other types of clays must be subjected to thermal treatment to generate their reactivity by dehydroxylation. This is the case of chlorite, illite, montmorillonite, bentonite, low-purity mica clay, and muscovite (Mohammed, 2017). In general, clays are composed of silica and alumina (phyllosilicates) that show pozzolanic activity when calcined. Also, other phases as feldspar, quartz, carbonates, and metal oxides are components of clays (Baronio \& Binda, 1997; Mohammed, 2017).

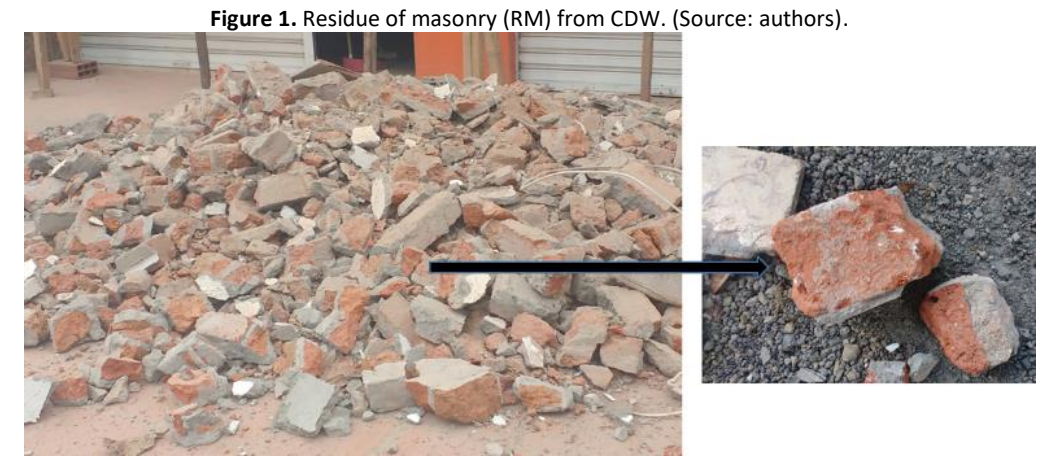

It is important to know the effects that RM can have on cement-based materials, that typically exhibit shrinkage due to self-desiccation, formation of hydration products and water loss (Li et al. 2017). The cementitious materials present different types of contraction such as autogenous shrinkage, chemical shrinkage and drying shrinkage. Among these types of shrinkage, the autogenous shrinkage is caused by further hydration of cement after the formation of initial structure of the cement. The capillary tension theory can explain this type of shrinkage (Lura, Jensen, \& van Breugel, 2003; Wu, Farzadnia, Shi, Zhang, \& Wang, 2017a). In general, the first hours are critical in the cementitious mixtures, since in this period the early-stage autogenous shrinkage occurs. The chemical shrinkage is due to concrete hydration to early ages (the hydration products formed have lower volume in comparison with the volume of the initial reactants). On the other hand, the internal loss of water in cement-based materials exposed to a low humidity environment shows a drying shrinkage (Toledo Filho, Ghavami, Sanjuán, \& England, 2005). The cracks in this type of shrinkage are due to self-desiccations mainly on the surface of the concrete elements (Yousefieh, Joshaghani, Hajibandeh, \& Shekarchi, 2017).

In this research, the effect of RM addition on mortars was investigated; to this aim, an experimental study including pozzolanic tests, setting time, hydration heat, autogenous and drying shrinkage, and compressive strength were done by replacing $12.5 \mathrm{wt} \%, 25 \mathrm{wt} \%, 37.5 \mathrm{wt} \%$ and $50 \mathrm{wt} \%$ of cement with RM.

Materials and methods

\section{Source materials}

Ordinary Portland cement (OPC) (type I - 42.5 MPa) according to ASTM C150/C150M and natural sand from river, with a maximum particle size of $2.36 \mathrm{~mm}$ (No. 8), were used for the preparation of mortars according to ASTM C305. Another OPC 1 (type I) was used for the pozzolanic evaluation with Ottawa sand. The residue of masonry (RM) was obtained by 
sampling from a CDW, that was collected from several remodeled houses in the city of Cali, Colombia. The RM was used as supplementary cementitious material, after being crushed and pulverized in a ball mill. The $D_{90}, D_{50}$ and $D_{10}$ values of RM were found to be $65.04 \mu \mathrm{m}, 15.89 \mu \mathrm{m}$ and $1.8 \mu \mathrm{m}$ by using a laser particle size analyzer (Mastersizer 2000 of Malvern Instruments). The RM partially replaced the OPC in 0\%, 12.5\%, 25\%, 37.5\% and 50\% by weight. Table 1 shows the characteristics and composition of Portland cements (OPC and OPC1) and the residue of masonry used. In order to get good compactability of the mortar mix, it was used a polycarboxylate based superplasticizer.

\begin{tabular}{|c|c|c|c|}
\hline Constituent (wt. \%) & OPC & OPC 1 & RM \\
\hline $\mathrm{SiO}_{2}$ & 16.03 & 17.99 & 56.86 \\
\hline $\mathrm{CaO}$ & 54.06 & 62.28 & 7.88 \\
\hline $\mathrm{Al}_{2} \mathrm{O}_{3}$ & 9.24 & 3.88 & 15.53 \\
\hline $\mathrm{Fe}_{2} \mathrm{O}_{3}$ & 0.63 & 4.76 & 7.63 \\
\hline $\mathrm{MgO}$ & 4.78 & 1.71 & 2.95 \\
\hline $\mathrm{K}_{2} \mathrm{O}$ & 1.63 & 0.32 & 1.36 \\
\hline $\mathrm{SO}_{3}$ & 3.60 & 4.03 & 0.55 \\
\hline $\mathrm{Na}_{2} \mathrm{O}$ & 1.17 & 0.23 & 2.49 \\
\hline LOI* & 1.50 & 4.14 & 3.39 \\
\hline Specific Gravity & 3.15 & 3.10 & 2.63 \\
\hline Mean particle size $(\mu \mathrm{m})$ & - & 21.65 & 24.09 \\
\hline Setting time initial (min) & 96 & - & - \\
\hline Setting time final (min) & 233 & - & - \\
\hline
\end{tabular}

*LOI: Loss on ignition.

X-Ray diffractogram (XRD) analysis of RM is shown in Figure 2. The XRD pattern of RM, indicate that the main phases of this residue are quartz $\left(\mathrm{SiO}_{2}\right)$, cordierite $\left(\mathrm{Mg}_{2} \mathrm{Al}_{4} \mathrm{Si}_{5} \mathrm{O}_{18}\right)$, hematite $\left(\mathrm{Fe}_{2} \mathrm{O}_{3}\right)$, phillipsite $\left(\mathrm{H}_{24} \mathrm{Al}_{6} \mathrm{Ca}_{2} \mathrm{~K}_{2} \mathrm{O}_{44} \mathrm{Si}_{10}\right)$, anorthite $\left(\mathrm{NaAl}_{2} \mathrm{Si}_{2} \mathrm{O}_{8}\right)$ and calcite $\left(\mathrm{CaCO}_{3}\right)$.

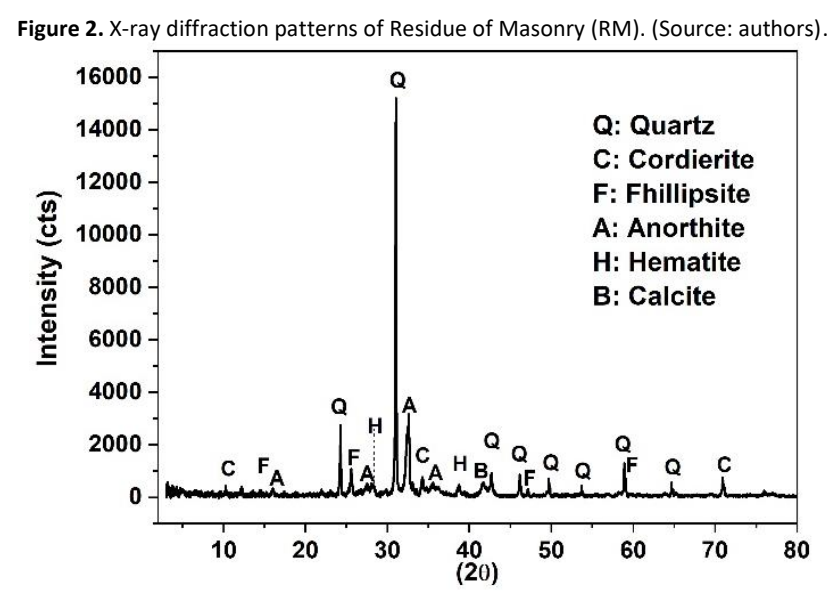

\section{Pozzolanic characterization Residue of masonry}

The characterization of the pozzolanic activity of RM was measured using different methods and tests such as thermogravimetric analysis, Frattini test and strength activity index (SAI). The derivative thermogravimetric (DTG) was performed on a SDT Q600 equipment, in an atmosphere of nitrogen and a heating rate of $10^{\circ} \mathrm{C} / \mathrm{min}$ using alumina crucible. By this technique, the consumption and the identification of formation of the portlandite phase are determined. For this analysis, pastes were made with $100 \%$ OPC (reference) and $80 \%$ OPC with $20 \%$ RM (20\% RM) and water/binder ratio of 0.28 . The paste samples were analyzed at 28 and 180 days of curing. To calculate the percentage of fixed lime $(\% \mathrm{CH})$, the following equation was used (Payá, Monzó, Borrachero, \& Velázquez, 2003; Soriano et al., 2013):

$$
\text { Fixed lime } \mathrm{Ca}(\mathrm{OH})(\%): 100\left(\frac{[\mathrm{CHc} \times \mathrm{C} \%]-\mathrm{CH} p}{\mathrm{CHc} \times \mathrm{C} \%}\right)
$$

Where $\mathrm{CH}_{\mathrm{C}}$ is the amount of portlandite in the paste with $100 \%$ OPC (reference) for a given curing time, $\mathrm{CH}_{\mathrm{P}}$ is the amount of portlandite present in the paste with $80 \mathrm{wt} \%$ OPC - $20 \mathrm{wt} \% \mathrm{RM}(20 \% \mathrm{RM})$ at the same curing age and C\% is the amount of OPC present in the pozzolanic paste (per unit mass) (Payá et al., 2003). 
The frattini test evaluates the consumption of calcium hydroxide $(\mathrm{CH})$ due to the pozzolanic reaction that is generated during the hydration of the Portland cement. This test was carried out according to the procedure described by NTC 1512. In this method, the test sample were prepared with $80 \%$ OPC and $20 \%$ RM by mass and mixed in an aqueous solution. After preparation, samples were left for 7 and 28 days in a sealed plastic container in an oven at $40 \mathrm{C}$. According to the maximum amount of calcium hydroxide with which pozzolan can combine and the rate at which this reaction occurs, the material will be located in the pozzolanic zone (below the solubility isotherm) or non-pozzolanic zone of the saturation curve.

The strength activity index (SAI) is the ratio of the compressive strength for mortar with $20 \%$ OPC replacement for pozzolan by mass to the compressive strength of a control mortar (100\% OPC). According to ASTM C618 the SAI value for the mix should be at least $75 \%$ at 28 days. This test was evaluated on mortars made with standard sand (Ottawa sand) (1:2.75, cement: sand proportion), and $w / b$ ratio of 0.55 . The compressive strength was determined at 28 days of curing using the average of three specimens.

\section{Mortar preparation (setting time, Shrinkage test and compression strength)}

The mortar mixtures were mixed according to the ASTM C 305 standard. The ratio of binder and sand was $1: 2$, and the water/binder ratio was 0.4 . Table 2 shows the mix proportions of mortars. The mortars containing $0,12.5 \mathrm{wt} \%, 25 \mathrm{wt} \%$, $37.5 \mathrm{wt} \%$ and $50 \mathrm{wt} \%$ of RM were molded in $5 \mathrm{~cm} \times 5 \mathrm{~cm} \times 5 \mathrm{~cm}$ cubes to test by compressive strength at 7, 28 and 56 curing days, following ASTM C 109; after $24 \pm 2$ hours, the specimens were unmolded and cured according to ASTM C511. The shrinkage studies were carried out using mortar prisms ( $25.4 \mathrm{~mm} \times 25.4 \mathrm{~mm} \times 285 \mathrm{~mm}$ ), that were sealed with aluminum tape to avoid any loss of moisture from the specimen to the surrounding atmosphere. Prisms without sealing were left for comparative purposes. The specimens were removed from the mold $24 \mathrm{~h}$ after casting. The specimens were placed in air storage at a relative humidity of $50 \pm 2 \%$ and temperature $75 \pm 3^{\circ} \mathrm{F}\left(23 \pm 2{ }^{\circ} \mathrm{C}\right)$.

\begin{tabular}{lccccc}
\multicolumn{7}{c}{ Table 2. Proportions of mortar mixtures (g). (Source: authors) } \\
\hline Mixture & PC & RM & Water & Sand & SP \\
\hline Reference & 100.0 & - & 40 & 200 & 0.25 \\
12.5\% RM & 87.5 & 12.5 & 40 & 200 & 0.25 \\
$25 \%$ RM & 75.0 & 25.0 & 40 & 200 & 0.25 \\
$37.5 \%$ RM & 62.5 & 37.5 & 40 & 200 & 0.25 \\
$50 \%$ RM & 50.0 & 50.0 & 40 & 200 & 0.25 \\
\hline
\end{tabular}

\section{Mortar testing methods}

\section{Setting time}

The initial and the final setting times were determined with a needle of a cross-sectional area of $65 \mathrm{~mm}^{2}$ attached to the loading apparatus (INSTRON 4502), according to ASTM C403. This arrangement was fixed in the laboratory of concretes in the University of Illinois (Urbana- Champaign). The experimental testing was totally done in the same university.

\section{Hydration heat}

The heat of hydration of mortars containing RM was measured using isothermal calorimetry (TAM air 8-channel, TA Instruments). The reaction rate of cement with water can be determined by heat released (Ahmad, Ahmad, \& Alam, 2018). For this, the isothermal calorimeter, which measures the heat flow, was set at a temperature of $22{ }^{\circ} \mathrm{C}$. For each test, $50 \mathrm{~g}$ of material was mixed in a plastic container using a spatula; however, it is known, that the shearing conditions can affect hydration kinetics of alite phase (tricalcium silicate) in pure Portland cement pastes (Juilland, Kumar, Gallucci, Flatt, \& Scrivener, 2012; Suraneni \& Weiss, 2017). Immediately after mixing, $17 \pm 0.2 \mathrm{~g}$ of material was transferred into a glass calorimeter ampoule, which was then placed in an isothermal calorimeter. The heat flow from the samples was recorded for 48 hours.

\section{Shrinkage}

The linear shrinkage (sealed and non sealed) of the samples was measured according to ASTM C157 (Figure 3). The length (Lt) was measured at 1, 8, 14, 21, 28, 42 and 56 curing days after the initial measurements. The mass of each specimen was also recorded during each measurement using a balance with an accuracy of $0.1 \mathrm{~g}$. The autogenous shrinkage of mixtures was measured following ASTM C1698, where it was used corrugated plastic tubes of $440 \mathrm{~mm}$ 
length (diameter of $28.5 \mathrm{~mm}$ ) (Figure 4). The shrinkage of the mortars at age of " $\mathrm{t}$ " days $(\varepsilon(\mathrm{t}))$ can be calculated as it is indicated in the equation 2.

$$
\varepsilon(t)=\frac{L o-L t}{250} X 100
$$

Where: Lo: the initial length of specimens; $L_{t}=$ the length of specimens measured at $1,8,14,21,28,42$, and 56 curing days. According to ASTM C157, the length change measurement was recorded by a device with a precision of $0.001 \mathrm{~mm}$.

Figure 3. Shrinkage test prisms for ASTM C157. a) Unsealed sample and b) sealed sample with aluminum tape. (Source: authors).
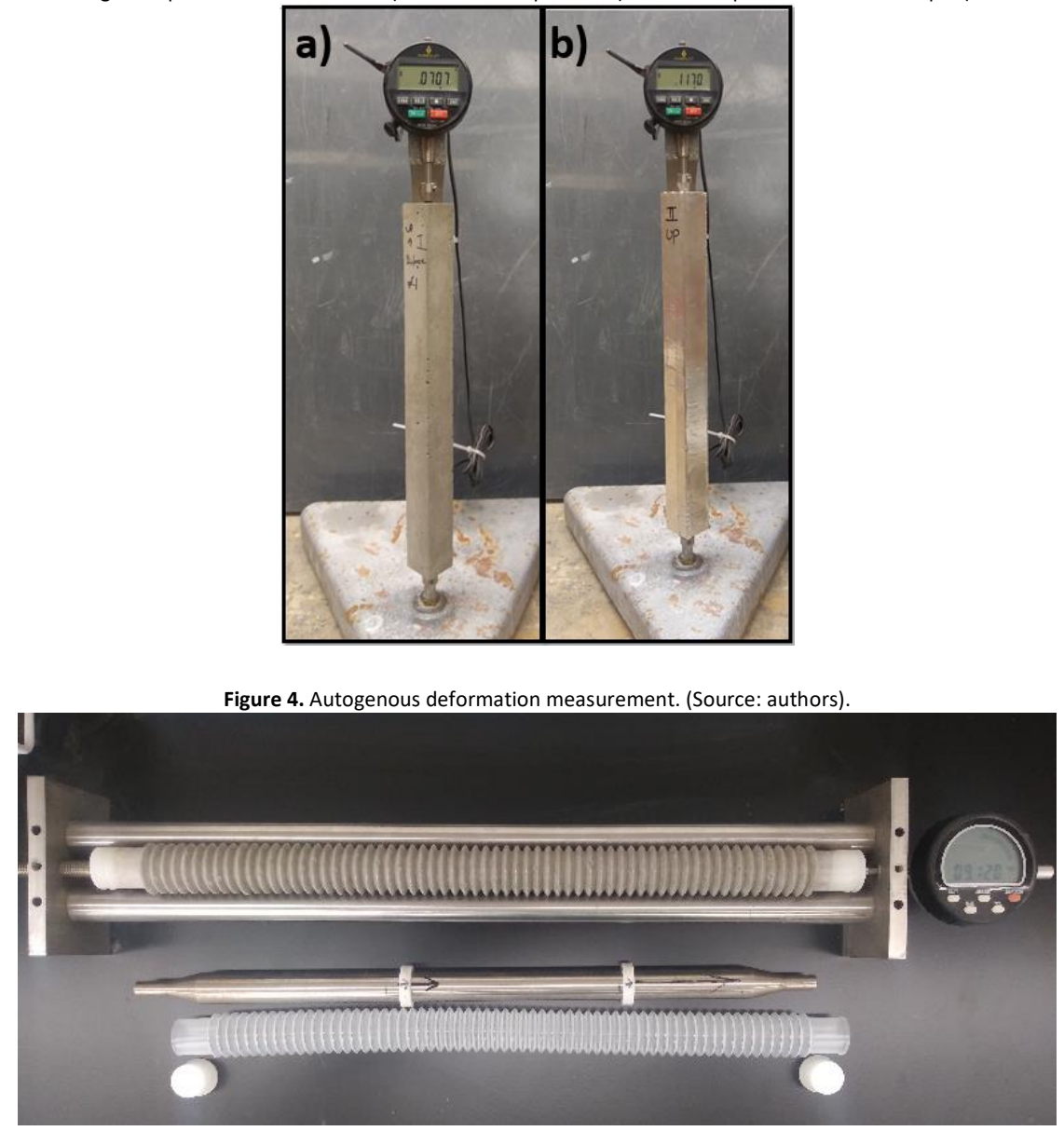

\section{Compressive strength}

The compressive strength of mortar mixes prepared were determined in cube of $50.8 \mathrm{~mm} \times 50.8 \mathrm{~mm} 50.8 \mathrm{~mm}$ according to ASTM C109 at 7, 28 and 56 days of curing. The strength values given in this study are the average of five specimens

\section{Pozzolanic activity of RM}

The derivative thermogravimetric (DTG) curves of the paste (Reference and 20\% RM) for 28 and 180 days are shown in Figure 5. It can be seen in the curves the dehydroxylation processes for the hydrated phases during cement hydration and the pozzolanic reactions (Frías, García, de la Villa, \& Villar, 2013; Frías, Vigil de la Villa, García, Martínez-Ramírez, \& Fernández-Carrasco, 2018) in the pastes $100 \%$ OPC I and $80 \%$ OPC I and $20 \%$ RM. The first peak located below $100^{\circ} \mathrm{C}$ is due to the evaporation of free water. This effect is more pronounced for the paste with $20 \%$ RM, due to the greater dilution effect presented in this mixture. The mass loss may be due to incomplete drying of the sample, but from $80^{\circ} \mathrm{C}$ the loss of water corresponds to the dehydration of the C-S-H (Gallucci, Zhang, \& Scrivener, 2013; Ma et al., 2018), in some cases, overlaps with the peak 2 corresponding to the decomposition of the ettringite (AFt), located in a temperature range between $100^{\circ} \mathrm{C}$ and $180^{\circ} \mathrm{C}$ (Izquierdo, Diaz, Mejía, \& Torres, 2013). Peak 3, in a range of $180-250^{\circ} \mathrm{C}$, is attributed to the calcium aluminosilicate hydrates (CASH) and calcium aluminates hydrates (CAH) present a 
dehydration process (Frías et al., 2018; Izquierdo et al., 2013). Peak 4 corresponds to an endothermic reaction located at about $420^{\circ} \mathrm{C}$, which is characteristic of the dehydration of portlandite (CH) (Ma et al., 2018). The peak 5, located close to $750^{\circ} \mathrm{C}$, is characteristic of the decomposition of various carbonates, mainly the calcium carbonate $\left(\mathrm{CaCO}_{3}\right)$, from the raw material and the possible carbonation of some phases (Yao, Liu, Wang, Wu, \& Lyu, 2019).
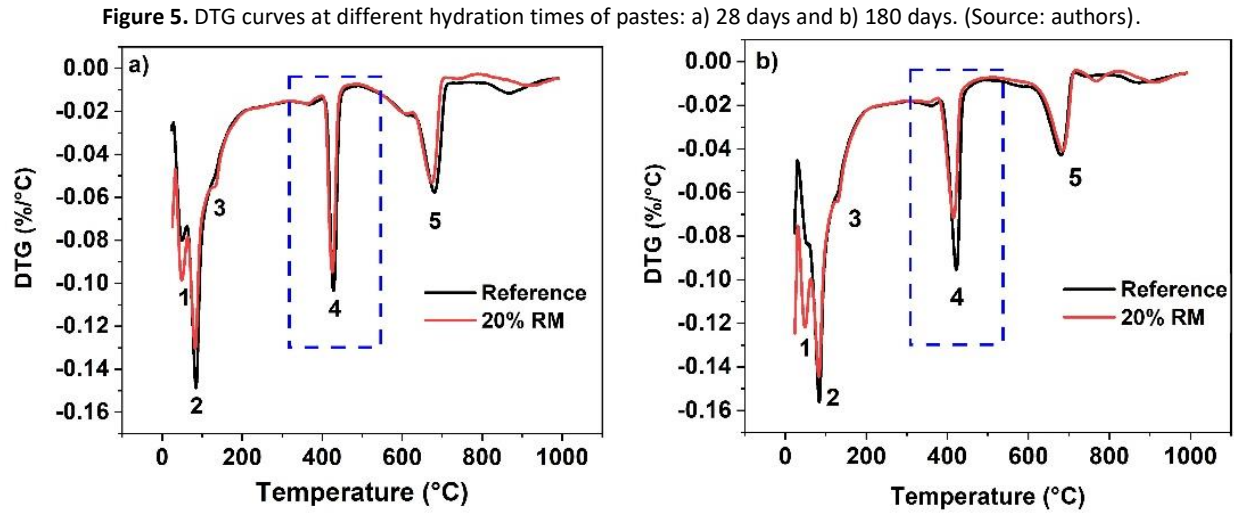

The pozzolanic effect was analyzed from peak 4 of the DTG by measuring the consumption of calcium hydroxide in the presence of RM, the difference in this peak at 180 days of curing is due to a decrease of weight loss and the portlandite content in the paste with RM. For this paste, the fixed lime values were $4.36 \%$ and $21.1 \%$ to 28 and 180 days, respectively. The positive values indicate that the residue of masonry presents pozzolanic reactivity.

The Figure 6 shows the test results of Frattini test for the cement paste with 20 wt\% RM at $40{ }^{\circ} \mathrm{C}$ for 7 and 28 days using the solubility isotherm for calcium hydroxide in an alkaline solution kept at the same temperature. After 7 days of contact amoung the materials, the RM does not show an acceptable pozzolanic activity because the consumption of calcium ions and the total alkalinity were not sufficient, so the RM is located above the isotherm of solubility of $\mathrm{Ca}(\mathrm{OH})$. However, at 28 days, the $\mathrm{CaO}$ concentration in the solution decreases as does the alkalinity, so that the RM managed to be located in the pozzolanic region or low saturation, which indicates that a large proportion of calcium hydroxide supplied during the hydration of Portland cement, it has been consumed by the pozzolanic reaction.

Figure 6. Frattini test at 7 and 28 days of OPC with RM replacement (Source: authors).

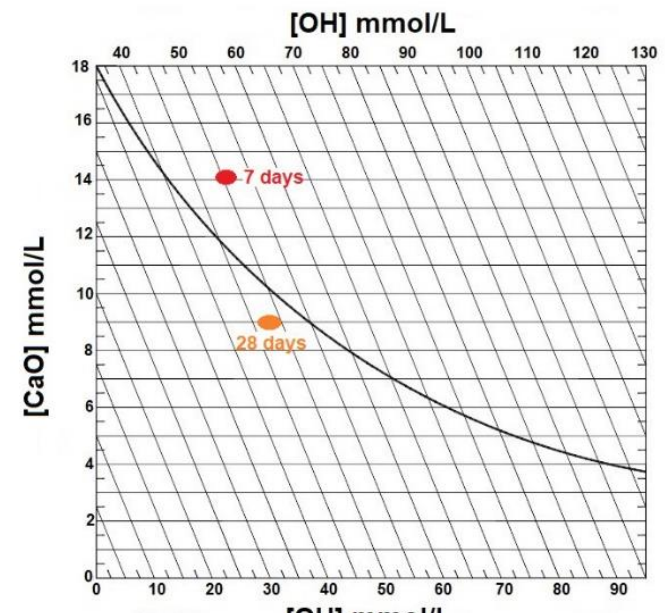

$[\mathrm{OH}] \mathrm{mmol} / \mathrm{L}$

The strength activity indexes (SAI) of mortars elaborated with RM are shown in Table 3. The SAI was $77.13 \%$ and $84.36 \%$ of the compressive strength of the Reference mortar at the 7 and 28 days, respectively. The increase in SAI at 28 days is attributed to the reaction of $\mathrm{RM}$ with $\mathrm{Ca}(\mathrm{OH})_{2}$ (Zeyad, Tayeh, \& Yusuf, 2019).

Table 3. Strength activity index (SAI) of mortar (Source: authors)

\begin{tabular}{lcc}
\hline \multicolumn{1}{c}{ Proportion } & 7 days strength (MPa) & 28 days strength (MPa) \\
\hline 100\% OPC & 27.55 & 35.32 \\
$80 \%$ OPC + 20\% RM & 21.24 & 29.82 \\
SAI & 77.13 & 84.36 \\
\hline
\end{tabular}




\section{Setting time}

The setting time of the mixtures was obtained according to the standard ASTM C403. The mortars were prepared as it is described by ASTM C305. Figure 7 shows the penetration resistance measurements versus time for mortar mixtures with different contents of RM. The initial setting time corresponds to a penetration resistance value of $3.5 \mathrm{MPa}$ and the final time comes at a penetration resistance value of $27.6 \mathrm{MPa}$. The measured setting times of all mixtures are shown in Table 4. It is seen that the final setting time increases as the percentage of cement replacement goes higher (except for the mixture with $12.5 \%$ of RM), this trend is like that got by Lin et al. (Lin, Chen, Chiou, \& An Cheng, 2010). This behavior can be attributed to the higher replacement of OPC to RM, which causes a dilution effect due to reduction of the major constituent phases of OPC as C3S and C2S (strength providers) (Mashaly, El-Kaliouby, Shalaby, EI - Gohary, \& Rashwan, 2016), since from these two phases the CSH gel is generated, which is responsible for the strength of pastes at an early age (Yuan, Zhou, Li, Huang, \& Shi, 2018). On the other hand, the reaction of RM is slow, thus the heat of hydration and strength development is low (Topçu, Uygunoğlu, \& Hocaoğlu, 2012).

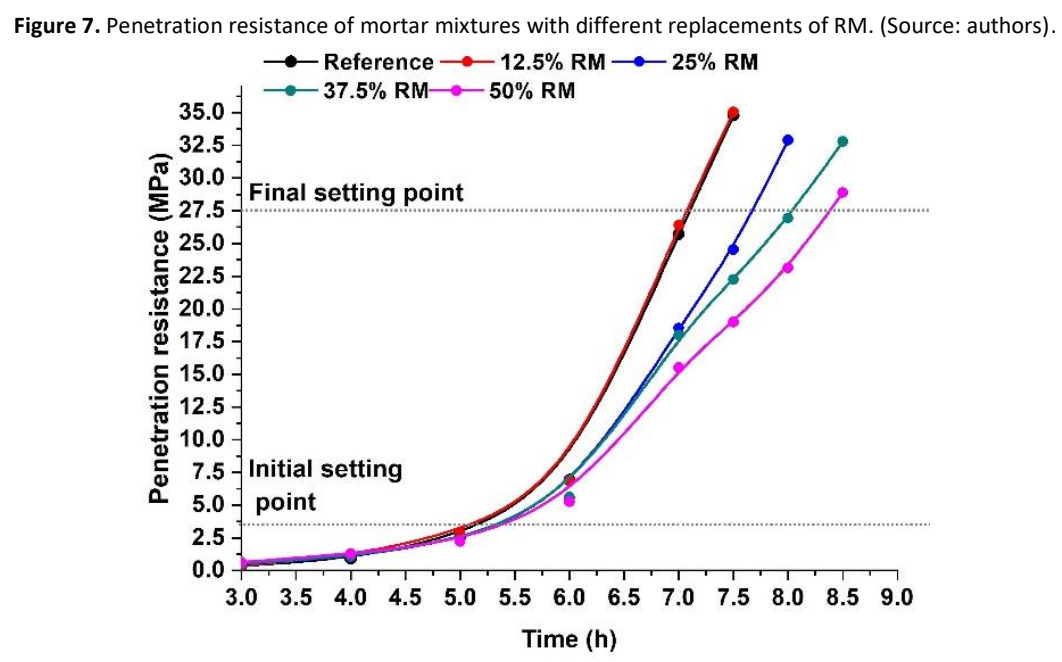

\begin{tabular}{lcccc}
\hline \multicolumn{5}{c}{ Table 4. Setting time (ASTM C 403). (Source: authors). } \\
Mix & Initial setting time $(\mathrm{h})$ & Standard deviation & Final setting time $(\mathrm{h})$ & Standard deviation \\
\hline Reference & 5.21 & 0.07 & 7.10 & 0.07 \\
$12.5 \%$ RM & 5.15 & 0.09 & 7.07 & 0.11 \\
$25 \%$ RM & 5.37 & 0.10 & 7.68 & 0.09 \\
$37.5 \%$ RM & 5.36 & 0.06 & 8.06 & 0.07 \\
$50 \%$ RM & 5.42 & 0.11 & 8.39 & 0.12 \\
\hline
\end{tabular}

\section{Hydration heat}

The Figure 8 shows the heat flow curves (calorimetric curves) of Reference mortar and mortars with different percentages of RM $(12.5 \%, 25 \%, 37.5 \%$, and $50 \%)$. The rate of heat generation per gram of cement $(\mathrm{mW} / \mathrm{g})$ is related to the hydration time in hours. According to Ahmad et al. (Ahmad et al., 2018), one of the mechanisms of reaction of the hydration of the OPC is related to the ionic phases of the clinker that result in a hydrate solution. In the other mechanism, topochemical reactions of the anhydrous cement phases take place, the products of these reactions remain insoluble. Figure 8 shows that the induction period has a similar trend in every mix, the beginning of hydration started almost at the same time. However, in the early hours, the presence of RM in mortars seems to speed up the hydration since the maximum heat flow value (Qmax) occurs earlier than that of the reference paste. This behavior can be attributed to the finely divided clay minerals that act as nucleation sites, accelerating cement hydration (CSH formation) (Zhou, Wang, Tyrer, Wong, \& Cheeseman, 2017).

During the acceleration period, all mortars containing RM presented the lower heat flow compared to Reference mortar (Cyr, Lawrence, \& Ringot, 2006; Gmür, Thienel, \& Beuntner, 2016). This is due to the dilution effect. The hydration of C3S influences the rate of acceleration and deceleration of heat evolution. When the OPC is replaced by RM, the hydration reaction is lowered due to the reduction of C3S. This peak becomes distinct by increasing the C3S content (lower replacement of cement by RM) (Frølich, Wadsö, \& Sandberg, 2016). Also, it is noted in this peak a lower formation of C-S-H, related to the hydration of calcium silicates (Uchima, Restrepo, \& Tobón, 2015). 
Some supplementary cementitious materials with high pozzolanic activity, such as silica fume and metakaolin, increases the heat of hydration, but adding others, like calcined clays, the reactions slow down (Gmür et al., 2016). The SCM can act as a filler (physical effect) manifesting its effect at an early age. The SCM (and fillers) with small particle sizes can improve reaction kinetics. (Juenger \& Siddique, 2015; Niewiadomski, Hoła, \& Ćwirzeń, 2018).

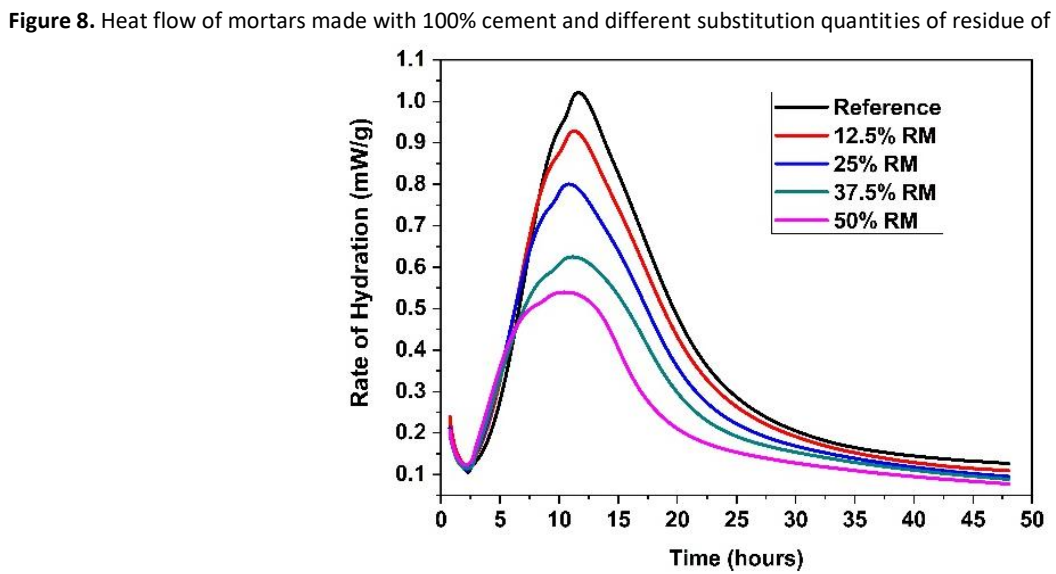

The accumulated heat of hydration $(\mathrm{J} / \mathrm{g}$ ) during 48 hours of the mortar with only OPC (Reference) and the mortars added with RM is shown in Figure 9. The highest heat released was presented by the reference mortar, and the lowest heat released was the mortar with $50 \% \mathrm{RM}$. In the first hours of hydration, the total heat liberated by the mortars containing RM was like that of the reference mortar. But the heat production after $12 \mathrm{~h}$ of hydration of the mortars containing RM was lower than that of the reference mixture.

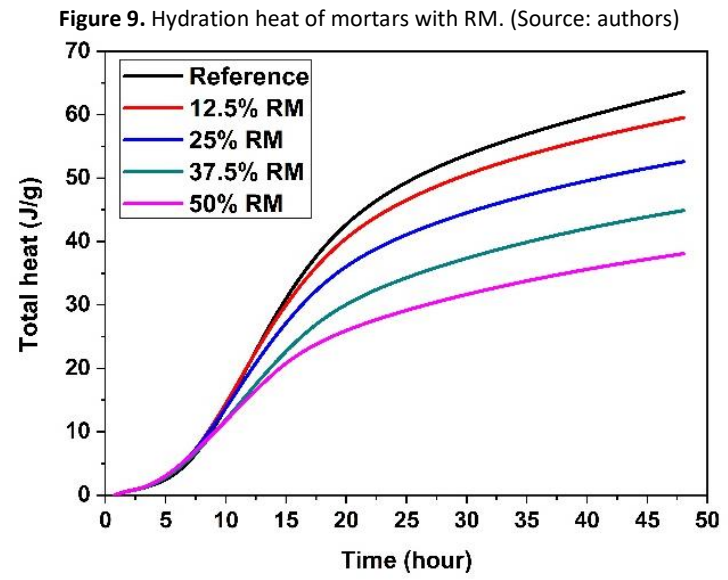

\section{Shrinkage length change (ASTM C157)}

Figure 10 shows the shrinkage developments of unsealed mortar mixture specimens. The free shrinkage of the mortars was measured after 24 hours of the start of the hydration process. Generally, the mortars with RM in its composition presented a lower drying shrinkage at an early age. This behavior is in agreement with that obtained by Zhu et al. (2016) and $\mathrm{Li}$ et al. (2020) who found that the addition of recycled waste powder composed of clay brick waste and old hardened cement paste as cement substitution would improve the shrinkage resistance. On the other hand, the reference mixture showed a faster drying shrinkage and a crescent development than the mortars with RM after 6 days. The reference mortar showed a higher drying shrinkage value than mortars with RM until 56 days of drying time. The results showed that the drying shrinkage of the reference mix was approximately $54 \%$ higher than that of the $50 \%$ RM at the 56 days. The lower drying shrinkage development of the mortars with RM was presumably attributed to the hydration rates of mortars, that were lower than the mortar with $100 \%$ OPC.

The RM is less reactive than the neat cement and produces a decrease of the shrinkage of mortars (Hu et al., 2017), this behavior is more evident when higher volumes of RM are proportioned. On the other hand, the pozzolanic reaction of RM and its refinement effects improved the pore structure at later times, besides resistance to shrinkage of mortars. In addition, when replacing cement by RM, the total composition of the mixture will present a smaller quantity of the main constituents of the cement, thus the heat input from C3S and C3A will be smaller, which means that the temperature 
gradient will be lower, which would cause a decrease in drying and autogenous shrinkage of mortars (Burrows, 1988; Wu, Farzadnia, Shi, Zhang, \& Wang, 2017b).In addition, the RM could reduce, to some extent, the self-shrinkage and shrinkage caused by water evaporation, since the moisture absorbed by RM could be released again to supply internal moisture to the cement (Cheng, 2016; Wu et al., 2017b).

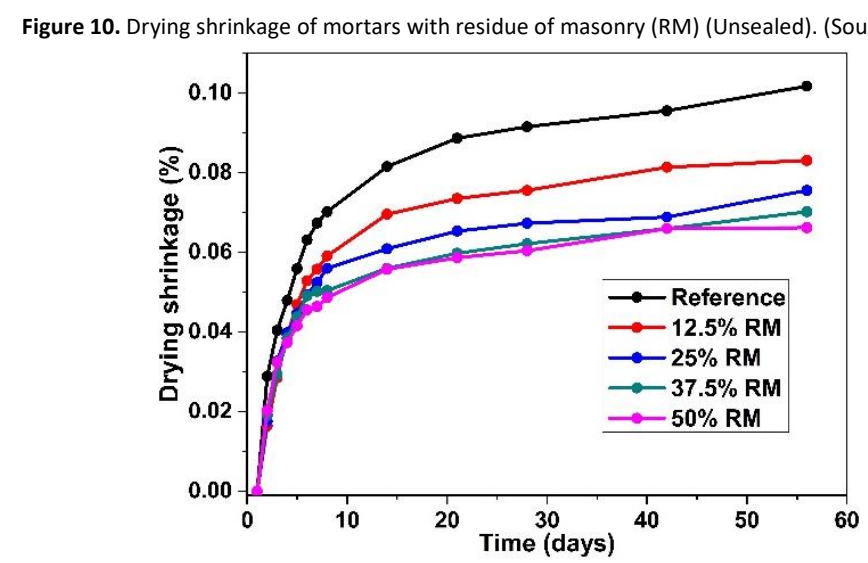

The shrinkage developments of mortar mixtures sealed are shown in Figure 11. The modification in the state of the test samples (sealed with aluminum tape) could be considered as a test for autogenous shrinkage since autogenous shrinkage refers to a reduction of length or of the apparent volume of paste, mortars or concrete under isothermal and seal conditions (Williams, Markandeya, Stetsko, Riding, \& Zayed, 2016; Wu et al., 2017b). However, in the sealed samples, there may have been a small opening near the screws that are in the prisms where a small loss of moisture could have been presented (section 3.5 shows the moisture loss).

In this study, the prismatic samples were wrapped (sealed) with aluminum adhesive tape after demolding. In Figure 11, it is shown that the greatest shrinkage is presented by the reference mortar, this may be due to mixes with water/cement ratio lower than 0.40 , the system (mortar) does not have enough internal moisture for the complete hydration of OPC particles in the mortar. The autogenous shrinkage has a high probability of increasing (Wu et al., $2017 b)$, also, a lower w/c ratio, results in a denser matrix increasing the capillary action, making greater the autogenous shrinkage due to self-desiccation (J. Liu, Ou, Mo, Wang, \& Wu, 2017).

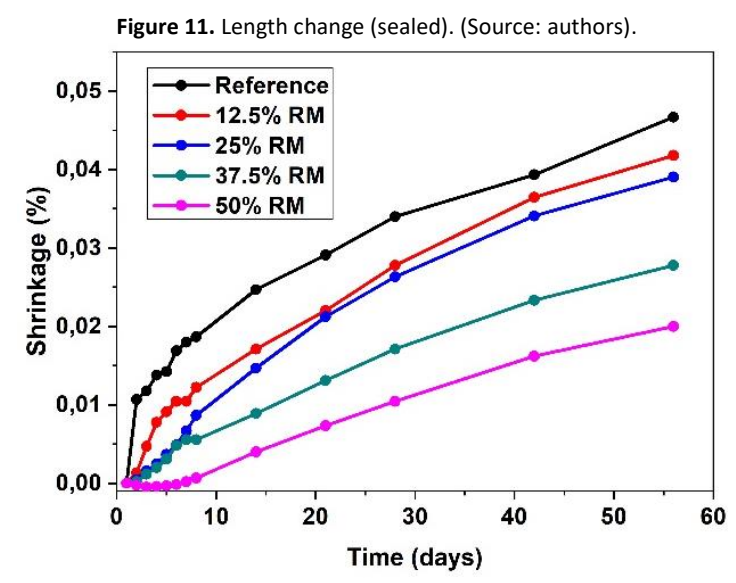

Mass loss of mortars incorporating RM (Water loss)

Figures 12 and 13 show the evolution of loss of water in unsealed and sealed prismatic specimens. A general analysis shows that all mortars mass decreased faster at an early age. The main reason is that the mixtures, after being removed from the mold, have a higher moisture content, furthermore, when the matrix generates a larger amount of C-S-H gel, there are decreases of porosity and pore volume, which reduces the evaporation of water (Jiang, Jin, Wang, Yan, \& Chen, 2018). The mortars with $37.5 \%$ and $50 \%$ of RM had the highest weight loss due to the higher water/binder effective ratio. In other words, the reduction of internal humidity of cement slurry, at an early age, in mixtures with higher cement content causes a significant increase of self-desiccation. However, the progress of hydration has a greater influence on the reduction of internal humidity. On the other hand, samples blended with RM have hydration rates much slower because of the sluggish pozzolanic reaction of this residue and that the loss of water at an early age is 
greater. This may be due to the filler effect that generates changes in hydration kinetics. The cement dilution that increases the water-cement ratio $(\mathrm{w} / \mathrm{c}$ ) produces a larger separation distance between cement particles (De la Varga, Castro, Bentz, Zunino, \& Weiss, 2018). For mixtures with higher w/c ratio (greater contents of RM), the increased pore size and amount of pores accelerates moisture loss.

It is appreciated, observing Figures 12 and 13, that the loss of water is greater in the unsealed mortars. During the first days, there is a greater loss of moisture, which stabilizes at about 14 days (unsealed samples), therefore the curing conditions are important for the first 14 days. However, in the sealed samples the increase in water loss is evident until 56 days.
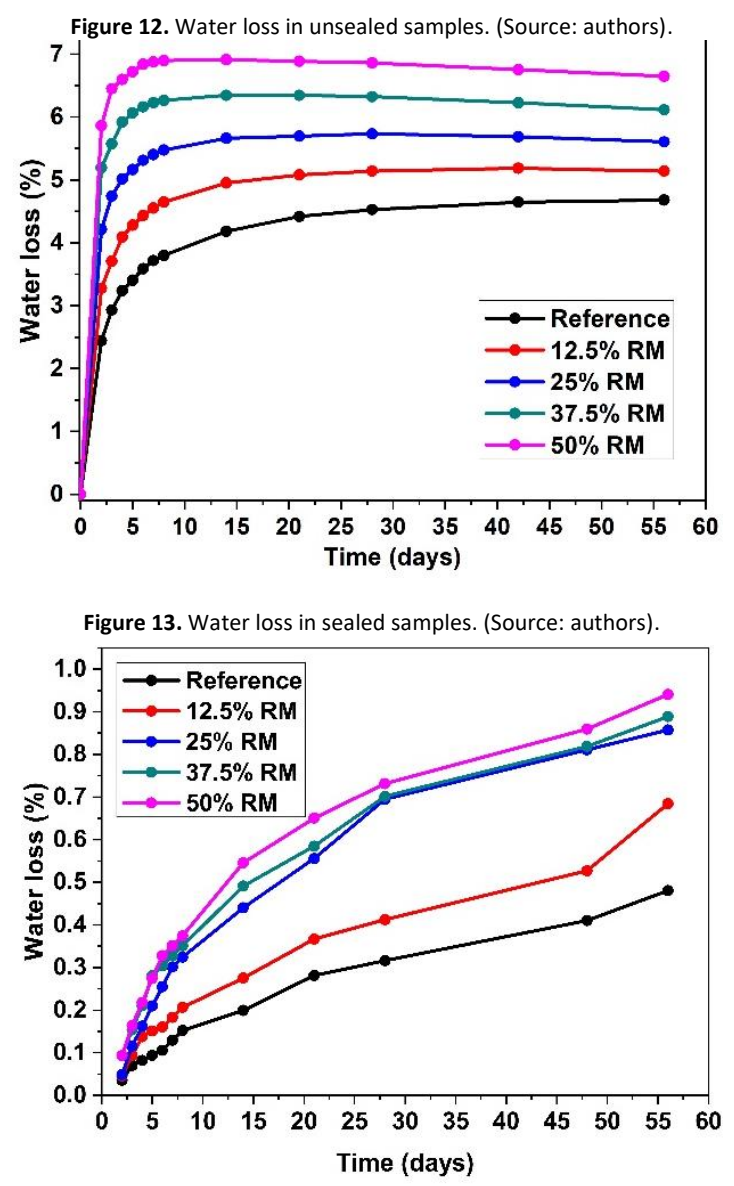

\section{Autogenous shrinkage (ASTM C 1698)}

Autogenous shrinkage is influenced by many factors, as cement type, fineness of cement, mineral admixtures, aggregates, water/cement ratio, curing, and admixtures. For example, higher contents of C3A and C3S in Portland cement cause more autogenous shrinkage. In other words, when replacing the cement by RM, the contents of C3A and C3S decrease, additionally to the effective water-binder ratio is higher which reduces the autogenous shrinkage. In addition, it has to be considered the slow reaction of the residue of masonry in comparison to cement. Another factor that reduces autogenous shrinkage is that RM can influence the internal curing of the mixture due to its high absorption. The RM releases the water inside mortar as the humidity of the material decreases, generating a saturation in the porosity of the paste, minimizing the autogenous stresses and strains (Ge, Wang, Sun, Wu, \& Guan, 2015).

The hydration of tricalcium silicate (C3S) presented in the clinker phase is greater in the reference mixture and in the one with lower RM content (as can be seen in the peak of the acceleration period in Figure 14 which is more distinct by increasing the C3S content). The gel C-S-H has a characteristic porosity so-called "gel pores" that have sizes between 5 $\AA$ to $100 \AA$. It could be expected that the mixture (containing more C-S-H gel) has more pores of this type. Consequently, it will have a higher capillary pressure due to the greater number of fine pores that will accelerate the autogenous shrinkage (Ghafari et al., 2016). 


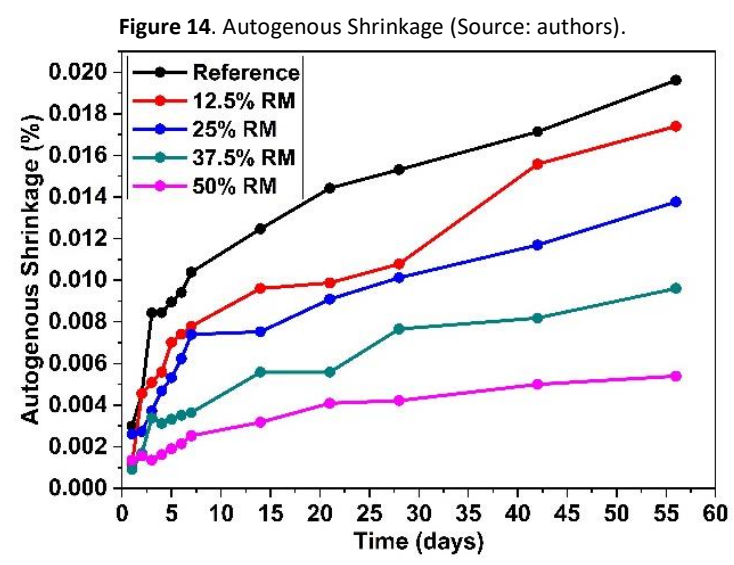

When comparing the shrinkage presented in the samples sealed with the aluminum tape (Figure 11) and to the mortars inside corrugated plastic tubes (Figure 14), a similar compartment can be observed. The reference mix presenting the highest shrinkage and the mortar with 50\% RM the lowest shrinkage in both tests. However, the shrinkage in the sealed specimens was greater due to the greater reduction of the internal relative humidity.

\section{Compressive strength}

The compressive strength of different mixtures at 7, 28, and 56 curing days are shown in Figure 15. All mortars show an increase in strength along curing time. This may be attributed to the hydration of OPC which generates changes in the structure of the paste. Also, it is seen that mortar with higher percentages of RM, the compressive strength decreased gradually, which was more remarkable for samples with $50 \%$ of this residue. However, reductions slowed down with longer curing times, being $20 \%-49.7 \%$ and $12.2 \%-39.4 \%$ at 7 and 56 days of curing, respectively. The reduction of compressive strength at early ages due to the low reactivity of this material (RM) and low generation of $\mathrm{CH}$ in the first days of curing. These results agree with those already found by Ge et al. (Ge et al., 2015). The authors noted that the compressive strength was significantly influenced by RM and that the reduction increased as the replacement level got greater and is more significant before 28 days.

When a supplementary cementitious material such as RM is used for replacement of cement, the effective w/c ratio is increased (Hu et al., 2017), besides, the interaction between particles is weaker due to the lower concentration of $\mathrm{Ca}^{2+}$ in pore solution resulting in lower strength. Also, blended Portland cement mixes with a large amount of SCMs, generally, at an early age, present lower mechanical properties in comparison with Portland cement mixes without addition. This phenomenon is generally attributed to the lower amount of calcium-silicate-hydrate present at an early age when SCM is used, resulting in a high porosity in the paste (S. Liu, Zhang, Guo, Wei, \& Yu, 2018).

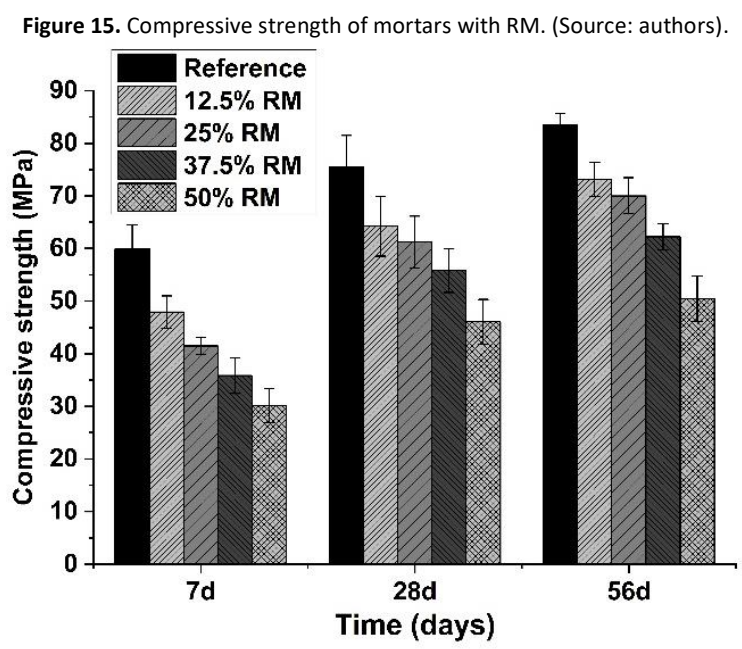


The test of fixed lime, Frattini, and strength activity index showed that the RM has, in some measure, pozzolanic behavior. The fixation of lime percentage at 28 and 180 days was $4.36 \%$ and $21.1 \%$, respectively. According to the Frattini test, the RM showed activity after 28 days, and The SAI was greater than $75 \%$.

The addition of RM decreases the total heat generation of a Portland cement mixture, although the incorporation of RM modifies the kinetics of hydration of clinker minerals in the first minutes. The mixture with $50 \%$ showed the lowest heat of hydration after $48 \mathrm{~h}$.

The addition of RM as partial substitution of Portland cement in mortars helps to reduce Portland cement consumption and mitigate environmental problems associated with the final disposal of RM.

The mixes with RM content present a reduced free drying shrinkage development at the first 56 days in comparison to the sample with only Portland cement.

The incorporation of RM to Portland cement mortar reduced the autogenous shrinkage (corrugated molds) by 11.3 , $29.8,51$, and $72.5 \%$ for $12.5 \% \mathrm{RM}, 25 \% \mathrm{RM}, 37.5 \% \mathrm{RM}$ and $50 \% \mathrm{RM}$, respectively. This due to the dilution and internal curing effect.

Autogenous shrinkage is lower when corrugated molds are used instead of sealing the samples with aluminum tape. This could be attributed to the fact that it is more hermetic, thus the loss of water would not influence in the shrinkage. The greatest loss of water of the mortars with RM occurs before 14 days, which is mainly caused by the hydration of the mixture, indicating that the curing conditions are important in the first 14 days.

The compressive strength of mortars cured under water decreased as the replacement rate increased from $0 \%$ up to $50 \%$ of RM. When percentages of replacements of $37.5 \%$ and $50 \%$ of OPC by RM were used, the influences were more significant after 7 days

\section{Acknowledgements}

The authors would like to thank: Universidad del Valle (Colombia), Grupo Materiales Compuestos (GMC), Centro de Excelencia de Nuevos Materiales (CENM, Universidad del Valle), and Colciencias- Minciencias for the support given to the Project 21060 "Aerogeles silíceas obtenidas de la cascarilla de arroz mediante un proceso químico sostenible para aplicaciones en superaislamiento térmico de edificaciones" convocatoria 808-2018 Proyectos de Ciencia, Tecnología e Innovación y su contribución a los retos de país- Colciencias. Código de Convenio: FP-141-2019. We also acknowledge the support given by professor David A. Lange and the Department of Civil Engineering, University of Illinois in UrbanaChampaign.

References

Ahmad, T., Ahmad, K., \& Alam, M. (2018). Investigating calcined filter backwash solids as supplementary cementitious material for recycling in construction practices. Construction and Building Materials, 175, 664-671. https://doi.org/10.1016/J.CONBUILDMAT.2018.04.227

Akhtar, A., \& Sarmah, A. K. (2018). Construction and demolition waste generation and properties of recycled aggregate concrete: A global perspective. Journal of Cleaner Production, 186, 262-281. https://doi.org/10.1016/J.JCLEPRO.2018.03.085

Andrew, R. (2018). Golbal $\mathrm{CO}_{2}$ emissios from cement production. Earth System Science Data, 10, 195-217. https://doi.org/10.5194/essd-10-195-2018

Baronio, G., \& Binda, L. (1997). Study of the pozzolanicity of some bricks and clays. Construction and Building Materials, 11(1), 41-46. https://doi.org/10.1016/S0950-0618(96)00032-3

Bediako, M. (2018). Pozzolanic potentials and hydration behavior of ground waste clay brick obtained from clamp-firing technology. Case Studies in Construction Materials, 8, 1-7. https://doi.org/10.1016/J.CSCM.2017.11.003

Burrows, R. W. (1988). M-11: The Visible \&amp; Invisible Cracking of Concrete. Retrieved from https://www.concrete.org/publications/internationalconcreteabstractsportal/m/details/id/51683284

Cheng, H. (2016). Reuse Research Progress on Waste Clay Brick. Procedia Environmental Sciences, 31, $218-226$. https://doi.org/10.1016/J.PROENV.2016.02.029

Construction and demolition waste - Environment - European Commission. (2017). Retrieved October 3, 2019, from https://ec.europa.eu/environment/waste/construction_demolition.htm

Cyr, M., Lawrence, P., \& Ringot, E. (2006). Efficiency of mineral admixtures in mortars: Quantification of the physical and chemical effects of fine admixtures in relation with compressive strength. Cement and Concrete Research, 36(2), 264-277. https://doi.org/10.1016/J.CEMCONRES.2005.07.001

De la Varga, I., Castro, J., Bentz, D. P., Zunino, F., \& Weiss, J. (2018). Evaluating the hydration of high volume fly ash mixtures using chemically inert fillers. Construction and Building Materials, 161, 221-228. https://doi.org/10.1016/J.CONBUILDMAT.2017.11.132 
de Oliveira Andrade, J. J., Possan, E., Squiavon, J. Z., \& Ortolan T.L.P. (2018). Evaluation of mechanical properties and carbonation of mortars produced with construction and demolition waste. Construction and Building Materials, 161, 70-83. https://doi.org/10.1016/J.CONBUILDMAT.2017.11.089

Dellinghausen, L. M., Gastaldini, A. L., Vanzin, F. J., \& Veiga, K. K. (2012). Total shrinkage, oxygen permeability, and chloride ion penetration in concrete made with white Portland cement and blast-furnace slag. Construction and Building Materials, 37, 652-659. https://doi.org/10.1016/J.CONBUILDMAT.2012.07.076

Frías, M., García, R., de la Villa, R. V., \& Villar, E. (2013). The effect of binary pozzolan mix on the mineralogical changes in the ternary activated paper sludge-fly ash- $\mathrm{Ca}(\mathrm{OH}) 2$ system. Construction and Building Materials, 38, 48-53. https://doi.org/10.1016/J.CONBUILDMAT.2012.08.045

Frías, M., Vigil de la Villa, R., García, R., Martínez-Ramírez, S., \& Fernández-Carrasco, L. (2018). New developments in low clinker cement paste mineralogy. Applied Clay Science, 166, 94-101. https://doi.org/10.1016/J.CLAY.2018.09.009

Frølich, L., Wadsö, L., \& Sandberg, P. (2016). Using isothermal calorimetry to predict one day mortar strengths. Cement and Concrete Research, 88, 108-113. https://doi.org/10.1016/J.CEMCONRES.2016.06.009

Gallucci, E., Zhang, X., \& Scrivener, K. L. (2013). Effect of temperature on the microstructure of calcium silicate hydrate (C-S-H). Cement and Concrete Research, 53, 185-195. https://doi.org/10.1016/J.CEMCONRES.2013.06.008

Ge, Z., Wang, Y., Sun, R., Wu, X., \& Guan, Y. (2015). Influence of ground waste clay brick on properties of fresh and hardened concrete. Construction and Building Materials, 98, 128-136. https://doi.org/10.1016/J.CONBUILDMAT.2015.08.100

Ghafari, E., Ghahari, S. A., Costa, H., Júlio, E., Portugal, A., \& Durães, L. (2016). Effect of supplementary cementitious materials on autogenous shrinkage of ultra-high performance concrete. Construction and Building Materials, 127, 43-48. https://doi.org/10.1016/J.CONBUILDMAT.2016.09.123

Gmür, R., Thienel, K.-C., \& Beuntner, N. (2016). Influence of aging conditions upon the properties of calcined clay and its performance as supplementary cementitious material. Cement and Concrete Composites, 72, 114-124. https://doi.org/10.1016/J.CEMCONCOMP.2016.05.020

Gutiérrez, A. S., Caballero Eras, J. J., Gaviria, C. A., Caneghem, J. V., \& Vandecasteele, C. (2017). Improved selection of the functional unit in environmental impact assessment of cement. Journal of Cleaner Production, 168, 463-473. https://doi.org/10.1016/J.JCLEPRO.2017.09.007

Harbi, R., Derabla, R., \& Nafa, Z. (2017). Improvement of the properties of a mortar with $5 \%$ of kaolin fillers in sand combined with metakaolin, brick waste and glass powder in cement. Construction and Building Materials, 152, 632-641. https://doi.org/10.1016/J.CONBUILDMAT.2017.07.062

Heikal, M., Zohdy, K. M., \& Abdelkreem, M. (2013). Mechanical, microstructure and rheological characteristics of high performance self-compacting cement pastes and concrete containing ground clay bricks. Construction and Building Materials, 38, 101-109. https://doi.org/10.1016/J.CONBUILDMAT.2012.07.114

Hu, X., Shi, Z., Shi, C., Wu, Z., Tong, B., Ou, Z., \& de Schutter, G. (2017). Drying shrinkage and cracking resistance of concrete made with ternary cementitious components. Construction and Building Materials, 149, 406-415. https://doi.org/10.1016/J.CONBUILDMAT.2017.05.113

Izquierdo, S., Diaz, J., Mejía, R., \& Torres, J. (2013). Cemento adicionado con un residuo del proceso de craqueo catalítico (FCC): hidratación y microestructura. Revista Ingeniería de Construcción, 28(2), 141-154. https://doi.org/10.4067/S0718-50732013000200003

Jiang, C., Jin, C., Wang, Y., Yan, S., \& Chen, D. (2018). Effect of heat curing treatment on the drying shrinkage behavior and microstructure characteristics of mortar incorporating different content ground granulated blast-furnace slag. Construction and Building Materials, 186, 379387. https://doi.org/10.1016/J.CONBUILDMAT.2018.07.079

Juenger, M. C. G., \& Siddique, R. (2015). Recent advances in understanding the role of supplementary cementitious materials in concrete. Cement and Concrete Research, 78, 71-80. https://doi.org/10.1016/J.CEMCONRES.2015.03.018

Juilland, P., Kumar, A., Gallucci, E., Flatt, R. J., \& Scrivener, K. L. (2012). Effect of mixing on the early hydration of alite and OPC systems. Cement and Concrete Research, 42(9), 1175-1188. https://doi.org/10.1016/J.CEMCONRES.2011.06.011

Kartini, K., Rohaidah, Zuraini, \& Za. (2012). Performance of Ground Clay Bricks as Partial Cement Replacement in Grade 30 Concrete. Retrieved from https://www.semanticscholar.org/paper/Performance-of-Ground-Clay-Bricks-as-Partial-Cement-KartiniRohaidah/826f9bff21da9fd99124dc3135ce79514df210ba

Li, H., Dong, L., Jiang, Z., Yang, X., \& Yang, Z. (2016). Study on utilization of red brick waste powder in the production of cement-based red decorative plaster for walls. Journal of Cleaner Production, 133, 1017-1026. https://doi.org/10.1016/J.JCLEPRO.2016.05.149

Li, L.G., Lin, Z.H., Chen, G.M., \& Kwan, A.K.H. (2020). Reutilizing clay brick dust as paste substitution to produce environment-friendly durable mortar. Journal of Cleaner Production, 274, 122787. https://doi.org/10.1016/j.jclepro.2020.122787

Li, W., Lang, L., Lin, Z., Wang, Z., \& Zhang, F. (2017). Characteristics of dry shrinkage and temperature shrinkage of cement-stabilized steel slag. Construction and Building Materials, 134, 540-548. https://doi.org/10.1016/J.CONBUILDMAT.2016.12.214

Lin, K.-L., Chen, B.-Y., Chiou, C.-S., \& An Cheng. (2010). Waste brick's potential for use as a pozzolan in blended Portland cement. Waste Management \& Research, 28(7), 647-652. https://doi.org/10.1177/0734242X09355853

Liu, J., Ou, Z., Mo, J., Wang, Y., \& Wu, H. (2017). The effect of SCMs and SAP on the autogenous shrinkage and hydration process of RPC. Construction and Building Materials, 155, 239-249. https://doi.org/10.1016/J.CONBUILDMAT.2017.08.061

Liu, P., Gao, Y., Wang, F., Yang, J., Yu, X., Zhang, W., \& Lu, Y. (2017). Superhydrophobic and self-cleaning behavior of Portland cement with lotus-leaflike microstructure. Journal of Cleaner Production, 156, 775-785. https://doi.org/10.1016/J.JCLEPRO.2017.03.211 
Liu, S., Zhang, T., Guo, Y., Wei, J., \& Yu, Q. (2018). Effects of SCMs particles on the compressive strength of micro-structurally designed cement paste: Inherent characteristic effect, particle size refinement effect, and hydration effect. Powder Technology, 330, 1-11. https://doi.org/10.1016/J.POWTEC.2018.01.087

Lura, P., Jensen, O. M., \& van Breugel, K. (2003). Autogenous shrinkage in high-performance cement paste: An evaluation of basic mechanisms. Cement and Concrete Research, 33(2), 223-232. https://doi.org/10.1016/S0008-8846(02)00890-6

Ma, B., Zhang, T., Tan, H., Liu, X., Mei, J., Qi, H., ... Zou, F. (2018). Effect of triisopropanolamine on compressive strength and hydration of cement-fly ash paste. Construction and Building Materials, 179, 89-99. https://doi.org/10.1016/J.CONBUILDMAT.2018.05.117

Maddalena, R., Roberts, J. J., \& Hamilton, A. (2018). Can Portland cement be replaced by low-carbon alternative materials? A study on the thermal properties and carbon emissions of innovative cements. Journal of Cleaner Production, 186 , 933-942. https://doi.org/10.1016/J.JCLEPRO.2018.02.138

Mashaly, A. O., El-Kaliouby, B. A., Shalaby, B. N., El - Gohary, A. M., \& Rashwan, M. A. (2016). Effects of marble sludge incorporation on the properties of cement composites and concrete paving blocks. Journal of Cleaner Production, 112, 731-741. https://doi.org/10.1016/J.JCLEPRO.2015.07.023

Medina, C., Zhu,W., Howind, T., Frías,M., \& de Rojas, M.I.S. (2015). Effect of the constituents (asphalt, clay materials, floating particles and fines) of construction and demolition waste on the properties of recycled concretes. Construction and Building Materials, 79 , 22-33. http://dx.doi.org/10.1016/j.conbuildmat.2014.12.070

Mohammed, S. (2017). Processing, effect and reactivity assessment of artificial pozzolans obtained from clays and clay wastes: A review. Construction and Building Materials, 140, 10-19. https://doi.org/10.1016/J.CONBUILDMAT.2017.02.078

Naceri, A., \& Hamina, M. C. (2009). Use of waste brick as a partial replacement of cement in mortar. Waste Management, $29(8), 2378-2384$. https://doi.org/10.1016/J.WASMAN.2009.03.026

Niewiadomski, P., Hoła, J., \& Ćwirzeń, A. (2018). Study on properties of self-compacting concrete modified with nanoparticles. Archives of Civil and Mechanical Engineering, 18(3), 877-886. https://doi.org/10.1016/j.acme.2018.01.006

Payá, J., Monzó, J., Borrachero, M. ., \& Velázquez, S. (2003). Evaluation of the pozzolanic activity of fluid catalytic cracking catalyst residue (FC3R). Thermogravimetric analysis studies on FC3R-Portland cement pastes. Cement and Concrete Research, 33(4), 603-609. https://doi.org/10.1016/S0008-8846(02)01026-8

Rezvani, M., \& Proske, T. (2017). Influence of chemical-mineralogical properties of limestone on the shrinkage behaviour of cement paste and concrete made of limestone-rich cements. Construction and Building Materials, 157, 818-828. https://doi.org/10.1016/J.CONBUILDMAT.2017.09.101

Seco, A., Omer, J., Marcelino, S., Espuelas, S., \& Prieto, E. (2018). Sustainable unfired bricks manufacturing from construction and demolition wastes. Construction and Building Materials, 167, 154-165. https://doi.org/10.1016/J.CONBUILDMAT.2018.02.026

Silva, Y. F., Robayo, R. A., Mattey, P. E., \& Delvasto, S. (2016). Properties of self-compacting concrete on fresh and hardened with residue of masonry and recycled concrete. Construction and Building Materials, 124, 639-644. https://doi.org/10.1016/J.CONBUILDMAT.2016.07.057

Soriano, L., Monzó, J., Bonilla, M., Tashima, M. M., Payá, J., \& Borrachero, M. V. (2013). Effect of pozzolans on the hydration process of Portland cement cured at low temperatures. Cement and Concrete Composites, 42, 41-48. https://doi.org/10.1016/J.CEMCONCOMP.2013.05.007

Suraneni, P., \& Weiss, J. (2017). Examining the pozzolanicity of supplementary cementitious materials using isothermal calorimetry and thermogravimetric analysis. Cement and Concrete Composites, 83, 273-278. https://doi.org/10.1016/J.CEMCONCOMP.2017.07.009

Toledo Filho, R. D., Ghavami, K., Sanjuán, M. A., \& England, G. L. (2005). Free, restrained and drying shrinkage of cement mortar composites reinforced with vegetable fibres. Cement and Concrete Composites, 27(5), 537-546. https://doi.org/10.1016/J.CEMCONCOMP.2004.09.005

Topçu, İ. B., Uygunoğlu, T., \& Hocaoğlu, i. (2012). Electrical conductivity of setting cement paste with different mineral admixtures. Construction and Building Materials, 28(1), 414-420. https://doi.org/10.1016/J.CONBUILDMAT.2011.08.068

Uchima, J. S., Restrepo, O. J., \& Tobón, J. I. (2015). Pozzolanicity of the material obtained in the simultaneous calcination of biomass and kaolinitic clay. Construction and Building Materials, 95, 414-420. https://doi.org/10.1016/J.CONBUILDMAT.2015.07.104

Uysal, M., Akyuncu, V., Tanyildizi, H., Sumer, M., \& Yildirim, H. (2019). Optimization of durability properties of concrete containing fly ash using Taguchi's approach and Anova analysis. Revista de La Construcción, 17(3), 364-382. https://doi.org/10.7764/RDLC.17.3.364

Williams, A., Markandeya, A., Stetsko, Y., Riding, K., \& Zayed, A. (2016). Cracking potential and temperature sensitivity of metakaolin concrete. Construction and Building Materials, 120, 172-180. https://doi.org/10.1016/J.CONBUILDMAT.2016.05.087

Wu, L., Farzadnia, N., Shi, C., Zhang, Z., \& Wang, H. (2017a). Autogenous shrinkage of high performance concrete: A review. Construction and Building Materials, 149, 62-75. https://doi.org/10.1016/J.CONBUILDMAT.2017.05.064

Wu, L., Farzadnia, N., Shi, C., Zhang, Z., \& Wang, H. (2017b). Autogenous shrinkage of high performance concrete: A review. Construction and Building Materials, 149, 62-75. https://doi.org/10.1016/J.CONBUILDMAT.2017.05.064

Yao, G., Liu, Q., Wang, J., Wu, P., \& Lyu, X. (2019). Effect of mechanical grinding on pozzolanic activity and hydration properties of siliceous gold ore tailings. Journal of Cleaner Production, 217, 12-21. https://doi.org/10.1016/J.JCLEPRO.2019.01.175

Yousefieh, N., Joshaghani, A., Hajibandeh, E., \& Shekarchi, M. (2017). Influence of fibers on drying shrinkage in restrained concrete. Construction and Building Materials, 148, 833-845. https://doi.org/10.1016/J.CONBUILDMAT.2017.05.093

Yuan, Q., Zhou, D., Li, B., Huang, H., \& Shi, C. (2018). Effect of mineral admixtures on the structural build-up of cement paste. Construction and Building Materials, 160, 117-126. https://doi.org/10.1016/J.CONBUILDMAT.2017.11.050 
Zeyad, A. M., Tayeh, B. A., \& Yusuf, M. O. (2019). Strength and transport characteristics of volcanic pumice powder based high strength concrete. Construction and Building Materials, 216, 314-324. https://doi.org/10.1016/J.CONBUILDMAT.2019.05.026

Zheng, L., Wu, H., Zhang, H., Duan, H., Wang, J., Jiang, W., ... Song, Q. (2017). Characterizing the generation and flows of construction and demolition waste in China. Construction and Building Materials, 136, 405-413. https://doi.org/10.1016/J.CONBUILDMAT.2017.01.055

Zhou, D., Wang, R., Tyrer, M., Wong, H., \& Cheeseman, C. (2017). Sustainable infrastructure development through use of calcined excavated waste clay as a supplementary cementitious material. Journal of Cleaner Production, 168, 1180-1192. https://doi.org/10.1016/J.JCLEPRO.2017.09.098

Zhu, P., Mao, X., Qu, W., Li, Z., \& Jhon Ma, Z. (2016). Investigation of using recycled powder from waste of clay bricks and cement solids in reactive powder concrete. Construction and Building Materials, 113, 246-254. https://doi.org/10.1016/j.conbuildmat.2016.03.040 